\title{
Responses of foraminiferal assemblages to ENSO climate patterns on bank reefs of northern Bahia, Brazil: A 17-year record
}

\author{
Francisco Kelmo $^{\mathrm{a}, *}$, Pamela Hallock ${ }^{\mathrm{b}, 1}$ \\ a Instituto de Biologia, Universidade Federal da Bahia, Campus de Ondina, Salvador, Bahia, CEP 40.170-115, Brazil \\ ${ }^{\mathrm{b}}$ College of Marine Science, University of South Florida, 830 1st Street South, St. Petersburg, FL 33701-5016, United States
}

\section{A R T I C L E I N F O}

\section{Article history:}

Received 5 December 2012

Received in revised form 4 February 2013

Accepted 4 February 2013

\section{Keywords:}

El-Niño

La Niña

Coral reefs

Foraminifera

Monitoring

Brazil

\begin{abstract}
A B S T R A C T
Benthic Foraminifera were assessed in Rose Bengal-stained sediment samples collected annually from 1995 to 2011 at four shallow bank reefs in Northern Bahia (Brazil). The assemblage was represented by 284 species and 88 genera, the most diverse genera being Quinqueloculina (46 spp.), Triloculina (24 spp.), Articulina (13 spp.), Textularia (11 spp.), and Elphidium (10 spp.). Significant differences in densities of live foraminifers in the sediments were observed among years, though not between reefs. Mean densities and diversities declined by 90\% during the 1997-8 El Niño event compared with the two previous years, then rebounded during the strong La Niña years of 1999-2000, with rapid recovery of populations of small, heterotrophic foraminifers in the assemblage. After 2000, mean densities and diversities fluctuated, with lows following both the 2006-7 and 2009-10 weak El Niño events, but not so pronounced as during the 1997-8 event. Multivariate analysis clearly formed four separate groupings representing strong (hot, dry) and weak El Niño (dry) years, "normal" years, and strong La Niña (high rainfall) years. The FoRAM Index (FI), which is a single-metric index for water quality associated with reef accretion, provided additional insights into assemblage responses. The FI compares relative abundances of three functional groups of benthic foraminifers: characteristic reef-dwelling larger foraminifers that host algal endosymbionts, the ubiquitous heterotrophic smaller taxa, and specifically stress-tolerant heterotrophic taxa. The striking decline in overall densities during El Niño years likely reflects reduced food supply for the heterotrophic taxa, associated with higher temperatures and reduced runoff. Decline in the taxa that host algal symbionts is consistent with reports of extensive coral bleaching, likely related to photo-oxidative stress caused by higher temperatures and increased water transparency. The significant changes in assemblage structure and composition recorded during this 17-year study demonstrate the major influence of climatic variability associated with the El Niño/La Niña-Southern Oscillation.
\end{abstract}

(C) 2013 Elsevier Ltd. All rights reserved.

\section{Introduction}

The Foraminifera are unicellular, eukaryotic protists that possess external tests typically made of calcite or agglutinatedsediment particles. These organisms are among the most common taxa found in sediments in all major reef systems around the globe (e.g. Langer et al., 1997; Langer, 2008; and references therein). Their distributions are influenced by a range of environmental factors, such as temperature, $\mathrm{pH}$, water motion, salinity, dissolved oxygen, turbidity, light intensity, food supply, substratum and sediment

\footnotetext{
* Corresponding author at: Marine and Coastal Ecology Research Group, Instituto de Biologia, Universidade Federal da Bahia, Rua Barão de Geremoabo, 147, Campus Universitário de Ondina, Salvador, Bahia, CEP. 40.170-115, Brazil.

Tel.: +55 713283 6522; mobile: +55 7199724716 .

E-mail addresses: kelmo@ufba.br, fkelmo@hotmail.com (F. Kelmo), pmuller@usf.edu (P. Hallock).

1 Tel.: +1 727553 1567; fax: +1 7275531189 .
}

texture, biotic interactions and taphonomic processes (e.g. Schafer, 2000; Martinez-Colón et al., 2009; and references therein). Many species have specific ecological niches (Ward et al., 2003) and quickly respond to temporal and spatial biotic and abiotic environmental changes (Schafer, 2000; Martinez-Colón et al., 2009; many others).

Existing knowledge of foraminiferal assemblages that occur in the coastal environments of northern Bahia (Brazil) is quite limited. Previous studies in the area (Andrade, 1997; Moraes, 2001, 2006; Machado et al., 2006) focused primarily on taxonomy, sedimentary geology, and taphonomy, with limited attention to biological and ecological aspects of the group. The most comprehensive study to date (Kelmo, 2002) was the first to record quantitatively the temporal and spatial patterns of biodiversity and assemblage composition of benthic foraminifers from surficial sediment of the coral reefs of northern Bahia.

The coastal belt of the State of Bahia has a tropical humid climate. Annual average rainfall ranges between $1300 \mathrm{~mm}$ in the north of the study area to $1900 \mathrm{~mm}$ around Salvador City to the 
south, with no marked seasonal rainfall pattern. Average daily air temperatures range from $23^{\circ} \mathrm{C}$ (winter) to $28^{\circ} \mathrm{C}$ (summer), with mean daily sea-surface temperatures ranging from $25^{\circ} \mathrm{C}$ (winter) to $28^{\circ} \mathrm{C}$ (summer); the maximum SST occurs between December and February each year. Annual average salinity varies little (35-36), although within reef-top shallow pools, salinity can range from 35 to 39. The $\mathrm{pH}$ of seawater varies only between 8.1 and 8.2, with no clear seasonal patterns (see Kelmo et al., 2003). The coast is influenced by winds arising from the NE and E during the spring-summer, and winds coming from the SE and E during the autumn-winter season. Moreover, during the autumn-winter period, the winds arising from the SSE, associated with the periodic advance of the Atlantic Polar Front, reinforce the trade winds from the SE (Bittencourt et al., 2000).

This pattern of wind circulation is disrupted by the quasicyclic environmental phenomenon known as the El Niño/La Niña Southern Oscillation (hereafter ENSO) and includes changes in the Atlantic Polar Front (Bittencourt et al., 2000), with several climatic perturbations recorded, such as severe drought (Rodrigues et al., 2011) and elevated seawater temperatures (Kumar et al., 2001). The 1997-8 El Niño event was one of the most intense on record and, in northern Bahia, started in mid-March 1997 and lasted until November 1998. The entire period was characterized by warmer air and sea temperatures, reduced cloud cover and rainfall, higher incoming solar radiation, and reduced turbidity (Kelmo et al., 2003). The large scale effects of this anomaly on many metazoans from the reefs of interest are well documented (Kelmo et al., 2004, 2006; Attrill et al., 2004) and included severe coral bleaching and mortality, as well intense bioerosion and reef degradation (Attrill and Kelmo, 2007).

Considering that severe disturbances associated with the 1997-8 El Niño were observed on coral reefs worldwide (Glynn et al., 2001), and that foraminiferal assemblages are well known to respond to environmental changes and therefore are used as indicators of reef vitality (Hallock et al., 2003), this paper presents the first long-term quantitative survey of reef-associated benthic foraminiferal assemblages spanning not only the 1997-8 event, but also the entire first decade of the 21st century. We discuss the influence of natural environmental disturbances imposed by ENSO-related variability on the structure and composition of the foraminiferal assemblages of shallow, bank-reef habitat in northern Bahia, Brazil, over a 17-year time series, demonstrating the role of ENSO as a dominant ecological mechanism in this region.

\section{Methods}

\subsection{Study area}

The bank reefs of northern Bahia are complex, elongated structures varying from 500 to $1800 \mathrm{~m}$ in length, and from 400 to $500 \mathrm{~m}$ in width, in water depths between 10 and $40 \mathrm{~m}$. The reefs are made up of discrete coral heads associated with coralline algae that have developed either on rock outcrops of various ages or on lines of Holocene beachrock (Nolasco and Leão, 1986). Their seaward margins are characterized by well-developed spur-and-groove systems. The reefs occur on the narrowest part of the Eastern Brazilian Continental Shelf (average width $15 \mathrm{~km}$ between two major rivers, São Francisco and Doce Rivers) and extend $20 \mathrm{~km}$ between the beaches of Abai $\left(12^{\circ} 40^{\prime} 04^{\prime \prime} \mathrm{S} / 38^{\circ} 04^{\prime} 47^{\prime \prime} \mathrm{W}\right)$ and Praia do Forte [12 $34^{\prime} 42^{\prime \prime} \mathrm{S} / 37^{\circ} 58^{\prime} 59^{\prime \prime} \mathrm{W}$ (see Fig. 1 in Kelmo and Attrill, 2001). The Pojuca River discharges in the vicinity of the study sites; the river's mean annual flow of $32 \mathrm{~m}^{3} \mathrm{~s}^{-1}$ was reduced to $20 \mathrm{~m}^{3} \mathrm{~s}^{-1}$ during the 1997-8 El Niño event. More detailed descriptions of the geological history and morphology of the reefs, as well as the climate of the region, can be found in Leão et al. (1997) and references therein.

\subsection{Sampling}

Environmental parameters for the survey area (sea-surface temperature, solar irradiance, air temperature, rainfall, and cloud cover) were obtained from the Brazilian Meteorological Institute (INMET). These data were collected three times a day and the values presented in this paper represent annual averages. INMET data are classified internationally in ISO9001.

Local physicochemical data (seawater temperature, salinity, $\mathrm{pH}$, and turbidity) were recorded across all four reef sites (10 replicates/reef providing 40 measurements during each sampling period). Such measurements were taken every month for the first 24 months to determine any seasonal patterns, which were only evident for temperature (Kelmo, 1998). Thereafter, replicated measurement of these variables was made only during the sampling month (due to logistical constraints after 1996), which was considered adequate to allow comparison between years. Temperature, salinity, and pH were recorded using a YSI63 (Yellow Spring Industries) electronic field meter (1995-2000), while turbidity was assessed using a Secchi disk, all deployed from a boat. Since 2001, we recorded turbidity and other local data using a Multiparameter Water Quality Meter (U5210); however, considering the similarity of the results, for reasons of uniformity we present the same types of measurements for the entire time series.

During April-May each year from 1995 to 2011, samples of surficial sediment were collected from the shallow bank of four different reefs of Northern Bahia (Praia do Forte, Itacimirim, Guarajuba and Abaí). Sampling was always performed in subtidal habitats during the low tide period, when tidal currents were weakest, by snorkelling or SCUBA diving. Ten $50 \mathrm{~g}$ surficial sediment samples were taken from each location, using a $50 \mathrm{~cm}^{3}$ diameter plastic core. The sediment sample was immediately transferred to a plastic receptacle and treated with a solution of ethanol and Rose Bengal (1 $\mathrm{g}$ Rose Bengal/1 L ethanol) according to Walton's (1952) protocol, to stain foraminifers that were live at the time of collection. This staining procedure has its limitations (Corliss and Emerson, 1990; Koukousioura et al., 2011), however, it is still the most common and practical method to quantify living foraminiferal assemblages (Murray and Bowser, 2000).

Samples were taken into the laboratory where they were oven dried for $48 \mathrm{~h}$ at a maximum temperature of $35^{\circ} \mathrm{C}$. The foraminifers were separated from the sediment by floatation. The dried sediment was poured gently into a beaker containing carbon tetrachloride, allowing the tests to float and the remaining grains to sink. The floating foraminifers were retained on filter paper and then transferred to individual pre-identified containers. The remaining sediment was examined under a stereoscope to guarantee that all foraminifers within the sample were assessed.

All tests stained brightly red, which were considered to have been alive when collected (Koukousioura et al., 2011; and references therein), were counted and identified using a stereomicroscope at high magnification. Authoritative keys and texts utilized included: Tinoco (1955, 1958), Narchi (1956), Barker (1960), Closs and Barberena (1960), Bock et al. (1971), Almasi (1978), Boltovskoy et al. (1980), Machado (1981), Leipnitz (1991), Leipnitz et al. (1992), Levy et al. (1995), Andrade (1997) and Rossi (1999). Selected specimens of small, difficult to identify species, were coated with $\mathrm{Au} / \mathrm{Pd} 200 \AA \AA$ pellicle and photomicrographs were obtained using a scanning electron microscope (Zeiss DSM 940A).

\subsection{Data analysis}

A triangular matrix of similarities between samples was computed using the similarity coefficient of Bray and Curtis (1957); the foraminiferal density data were first transformed $[\ln (x+1)]$ to reduce the influence of dominant species (Clarke and Warwick, 

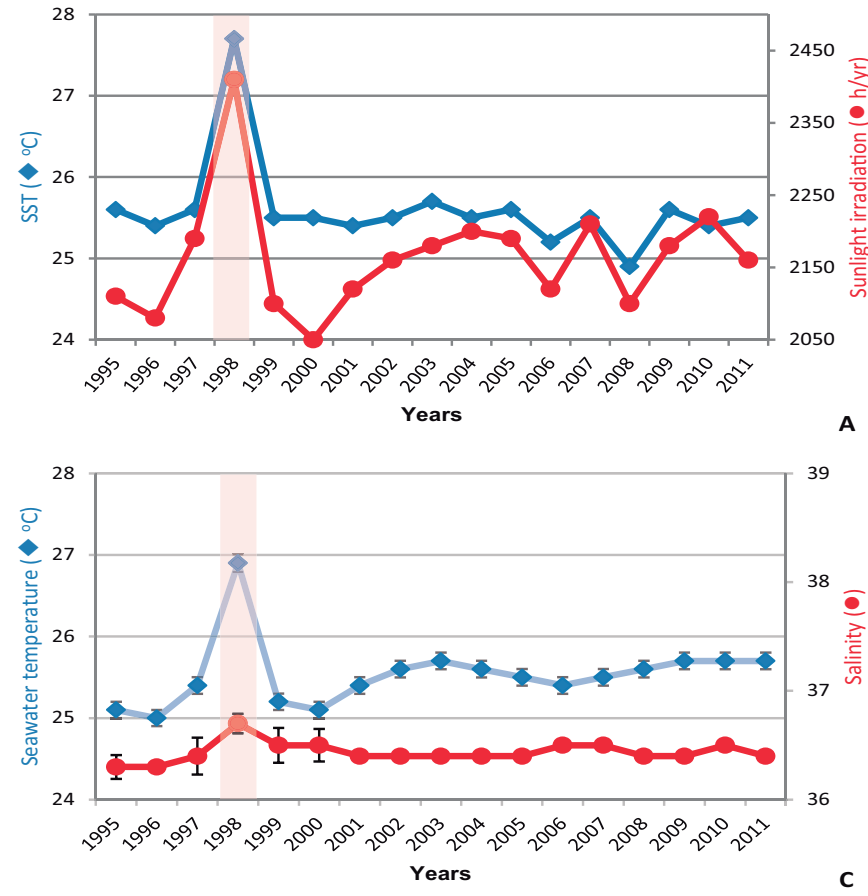

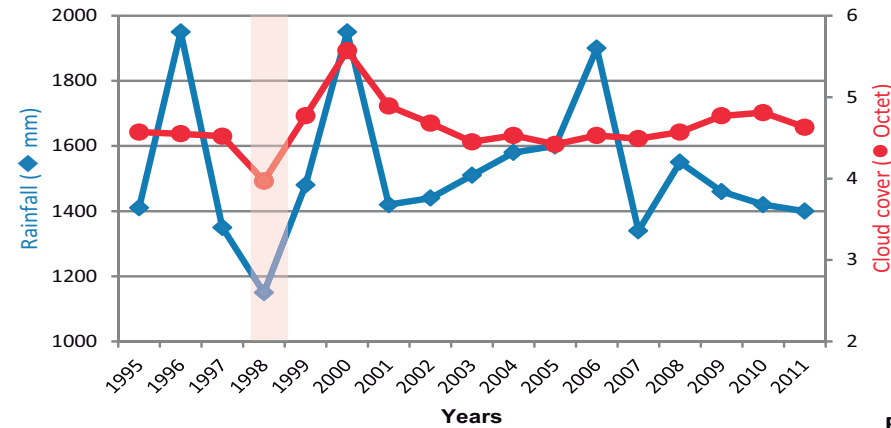

B

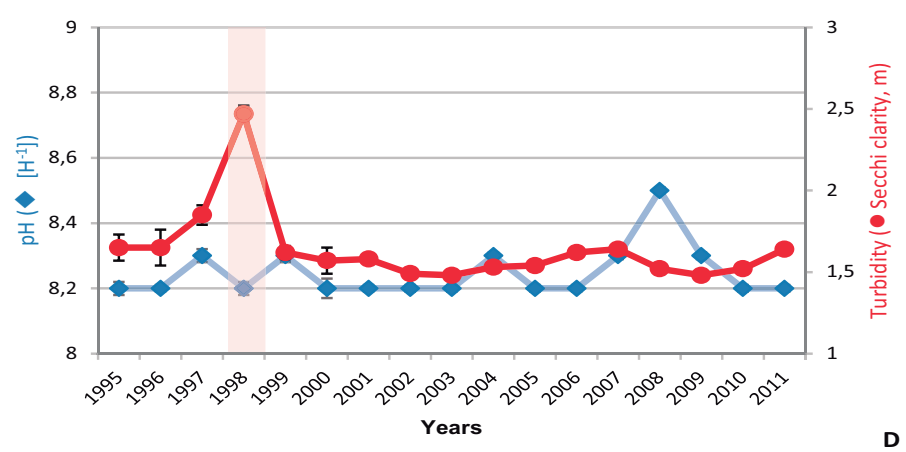

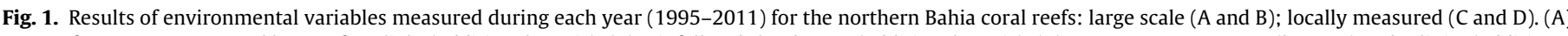

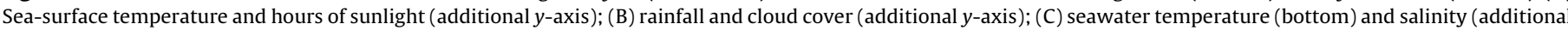

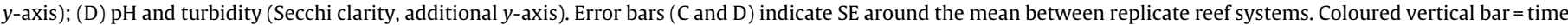
period of severe 1997-8 ENSO event.

1994). The similarity matrix was subjected to ordination analyses using the PRIMER (Plymouth Routines in Multivariate Ecological Research) package (Carr, 1996) and was visualized using non-metric multidimensional scaling (MDS). We used the SIMPER procedure (similarity percentages; Clarke, 1993) to exam the contribution of species to dissimilarities between the groupings observed in the ordination analyses. Differences in the foraminiferal assemblages across years were tested for significance using ANOSIM (Clarke and Green, 1988). The BIOENV method (Clarke and Ainsworth, 1993) was used to investigate the relationship between environmental variables (pre- and post-ENSO) and the foraminiferal assemblage data.

\subsection{FI Index}

The Foraminifera in Reef Assessment and Monitoring Index (FI), proposed by Hallock et al. (2003), also was used to assess Bahian foraminiferal assemblages. This single-metric index is based on foraminiferal assemblages from surface sediments and can be used to address local impacts and to assist in differentiating between local impacts that affect water quality and impacts that result from regional- to global-change issues, and has been used worldwide (Barbosa et al., 2009; Narayan and Pandolfi, 2010; Uthicke et al., 2010; Koukousioura et al., 2011). The FI involves summing of relative abundances into three functional groups: (i) symbiont-bearing taxa, (ii) stress-tolerant (opportunistic) taxa, and (iii) other small taxa. The FI is based on the assumption that environments suitable for proliferation of symbiont-bearing organisms have sediments in which at least $25-30 \%$ of the foraminiferal tests are produced by taxa that host algal symbionts (larger taxa). The FI interpretation of Hallock et al. (2003) as modified by Carnahan et al. (2009) is as follows: A sample that contains at least 25\% larger foraminifers and no more than $75 \%$ of other small taxa has a $\mathrm{FI} \geq 4$, indicating that water quality is likely suitable for reef growth. FI varying between 3 and 5 can indicate environmental change; values of $2<\mathrm{FI}<4$ indicates environmental conditions marginal for reef growth that likely are unsuitable for recovery of coral communities after a mortality event. Environments where larger foraminiferal tests are scarce and stress-tolerant taxa are common $(\mathrm{FI} \leq 2)$ are under stressed conditions and unsuitable for reef growth.

\section{Results}

The 1997-8 El Niño event had a significant influence on most of the measured environmental parameters (Fig. 1A-D). Mean air and seawater temperatures and hours of sunlight increased significantly in 1998 compared with all other years, the latter due to lower cloud cover. Rainfall was significantly lower during El Niño conditions and this resulted in reduced freshwater and sediment outflow from the local rivers (the mean annual discharge of the São Francisco River was reduced from 32,980 to $1768 \mathrm{~m}^{3} \mathrm{~s}^{-1}$ and that of Doce River from 80.5 to $50.2 \mathrm{~m}^{3} \mathrm{~s}^{-1}$ ) and thus, significantly clearer water. Therefore, the environmental conditions during 1998 were anomalously warm, with reduced cloud cover, increased insolation and reduced turbidity, resulting in more solar radiation reaching the reefs. In contrast, 1999-2000, and to a lesser extent, 1995-6 represented relatively strong La Niña conditions, as indicated by high rainfall and cloud cover (Fig. 1B).

The foraminiferal assemblage identified from the shallow-banks of Northern Bahia included 284 species and 88 genera, distributed in three functional groups: symbiont-bearing (16 spp.); stresstolerant (24 spp.) and other small forms ( $244 \mathrm{spp}$.). The most diverse genera were Quinqueloculina (46 spp.), Triloculina (24 spp.), Pyrgo (16 spp.), Articulina (13 spp.), Textularia (11 spp.) and Spiroculina (7 spp.). Among the symbiont-bearing forms the most diverse was Peneroplis (6 spp.), while within the stress-tolerant taxa, Elphidium (10 spp.) and Bolivina (6 spp.) were the most diverse. The mean densities of live foraminifers from the shallow, bank-reef sediments were highest in 1999-2000 followed by 1995-6, with the lowest 


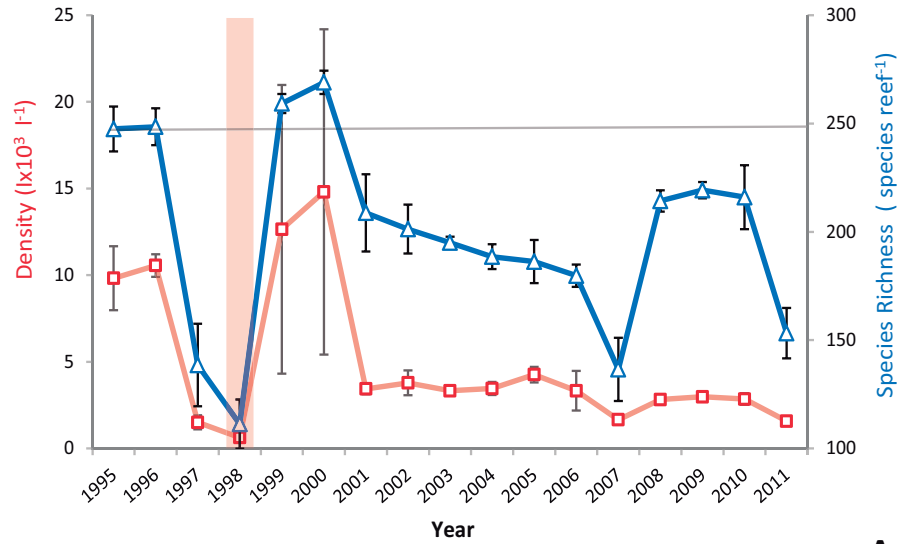

A

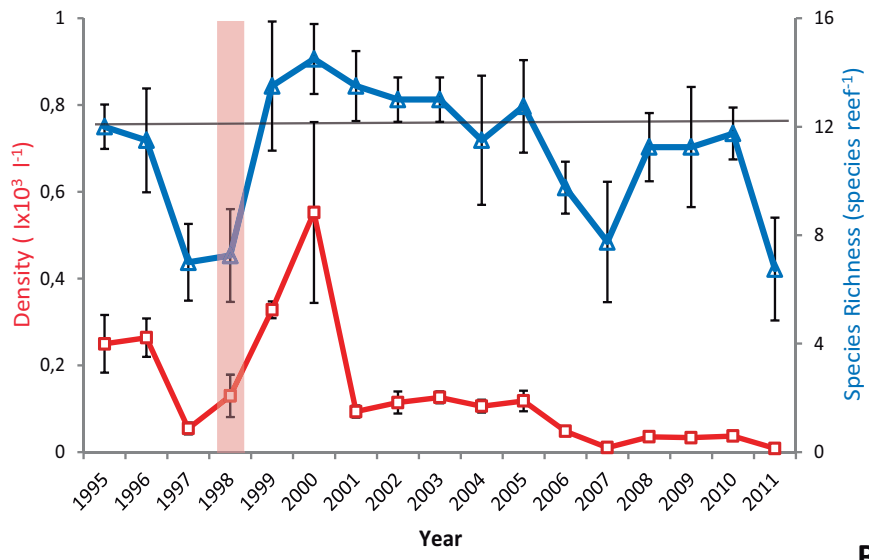

B
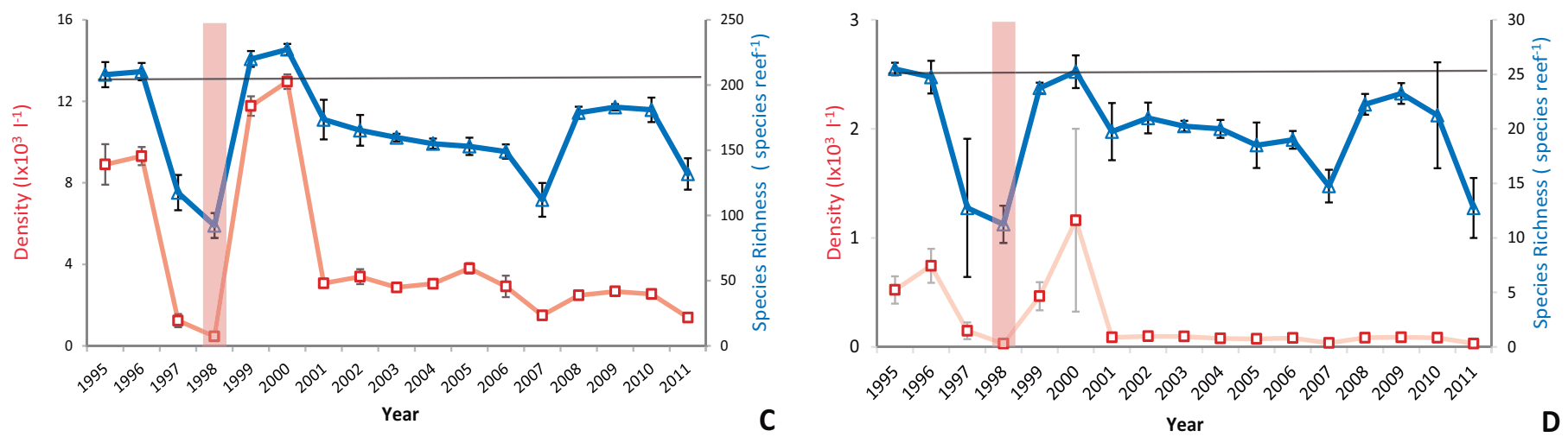

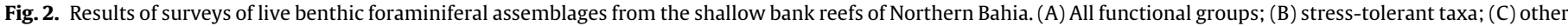

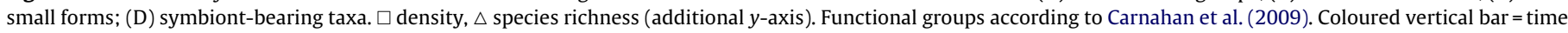

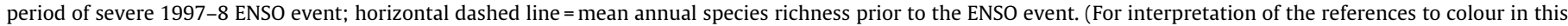
figure legend, the reader is referred to the web version of this article.)

densities in 1997-98, 2007 and 2011 (Fig. 2A). Diversity (species richness) followed similar trends.

The densities of all three functional groups of the foraminiferal assemblage fluctuated dramatically between 1995 and 2001; subsequent fluctuations were much lower in amplitude (Fig. 2B-D). Overall mean densities were relatively high in 1995-6, then dramatically decreased in 1997-8, rebounding in 1999-2000 to the highest densities observed during the 17-year study. Moreover, the 1999-2000 peak was driven primarily by high densities of smaller taxa, as the longer-lived, symbiont-bearing taxa recovered more slowly. After 2000 , densities were about $20-30 \%$ of the densities recorded during 1995-6, with no significant variation recorded until 2007, when densities dropped by roughly half, followed by a recovery for three years, dropping again in 2011 to values similar to those seen in 2007.

Variations in species richness (Fig. 2A-D) followed the same pattern as density, decreasing significantly, roughly $60 \%$, between 1995-6 and 1997-8. Species richness recovered in 1999-2000, then dropped by approximately 20\%, varying little between 2001 and 2006. However, a sudden reduction in species number was recorded in 2007 , followed by a recovery period of three years and another drop in 2011.

FI values (Fig. 3) oscillated between $2.5 \pm 0.01$ and $3.0 \pm 0.05$ during the study. The FI of $\sim 3$ during the first three years declined significantly in 1998 through 2000, with the lowest mean $[2.47 \pm 0.02($ mean $+S E)]$ in 2000. This low reflected the rapid recovery of population densities of the smaller, shorter-lived taxa compared to the longer-lived larger foraminifers following the 1997-8 density crash in all taxa. FI values increased slowly from 2001 to 2007 and returned to the initial range by 2011. This trend was primarily driven by the low but stable densities of larger foraminifers coupled with the modest decline in densities of smaller taxa. The FI peak in 2007 further indicates the relative stability of the densities of larger taxa as compared to the drop in densities of smaller taxa that year.

No significant differences in mean densities were observed between reefs ( 2 -way crossed ANOSIM, $R=0.06, p>0.1$ ). The MDS plot (Fig. 4) demonstrates significant changes in the assemblage structure during the study, clearly illustrating four separate groupings representing strong $(1997,1998)$ and weak $(2007,2011) \mathrm{El}$

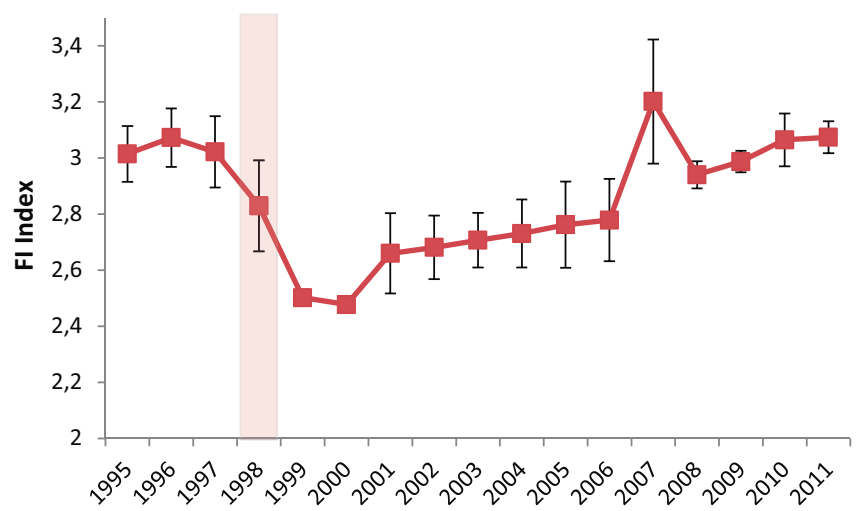

Fig. 3. Results of Foraminifera in Reef Assessment and Monitoring Index (FI) of the shallow-bank reefs assemblages from northern Bahia. Coloured vertical bar = time period of severe 1997-8 ENSO event. (For interpretation of the references to colour in this figure legend, the reader is referred to the web version of this article.) 


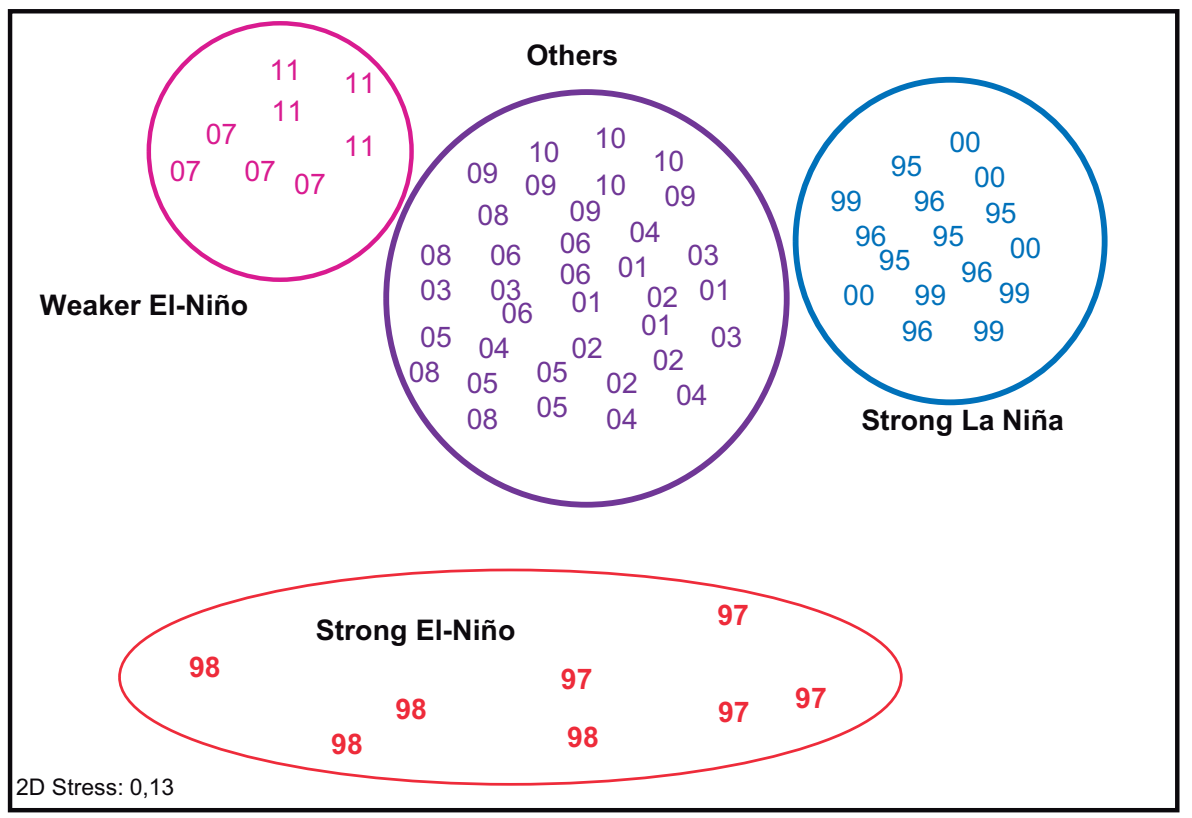

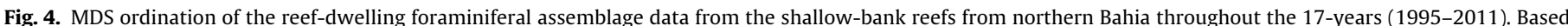
on $[\ln (x+1)]$ transformed species densities and Bray Curtis similarities. Codes refer to year of sampling (i.e. $00=2000)$.

Niño (drought) years, intermediate or "normal” years (2001-06, 2008-10), and the strong La Niña (high rainfall) years (1995, 1996, $1999,2000)$. The assemblages fluctuated most dramatically during the strong ENSO variability from 1995 through 2000, then subsequently remained more stable with lower intensity environmental variability from 2001 through 2011. Overall, significant changes (ANOSIM, $R=0.625 ; p=0.001$ ) were recorded in the assemblage structure over the 17 -year study.

The similarity percentages procedure (SIMPER) indicated that Planispirella exigua and Quinqueloculina bicostata were the two most commonly recorded species during years with higher densities, although each accounted for an average relative abundance of only $4.0 \%$. Miliolinella subrotunda and Textularia gramen were most common in low-density years, accounting for an average of only $3.0 \%$ each; $M$. subrotunda was actually more abundant in higher density years, with an average relative abundance of $3.9 \%$. Amphistegina gibbosa, Articulina atlantica, and Siphonina pulchra showed the greatest change between higher and lower density years, declining $2.05 \%, 1.76 \%$ and $1.74 \%$ respectively. Overall differences were due to declines in densities across large numbers of species rather than to large changes in a few species (Appendix A).

During the 1997-8 El Niño event, 27 species were not recorded at any of the studied reefs, returning in the following two years, then disappearing completely after 2000 (Appendix A). Additionally, another 19 species recorded during the 1997-8 El Niño, were not subsequently seen. Discorbis bertheloti, recorded during and after the first El Niño event, was not seen after 2003.

BIOENV analysis indicated that variation in turbidity $(r=0.41)$ was the environmental factor best explaining the foraminiferal assemblage differences on the assessed reefs overall. However, a combination of turbidity $(r=0.68)$, mean temperature $(r=0.71)$, and cloud cover $(r=0.64)$ best explained the changes in the assemblage in 1998.

\section{Discussion}

Foraminiferal populations and assemblages clearly respond to environmental changes (e.g. Hallock et al., 2006; Martinez-Colón et al., 2009; and references therein) and therefore are considered reliable indicators of environmental disturbances in both marine and estuarine environments (Schafer, 2000; Uthicke et al., 2010; many others). We recorded a dramatic decrease in density and species richness of Foraminifera from the studied reefs during 1997-8, as well as considerable changes in assemblage composition between times with strong and weak ENSO variability. Multivariate analyses (Fig. 4) revealed that the benthic foraminiferal assemblage responded strongly to ENSO-driven environmental fluctuations, with 47 species representing 13 genera not recorded during severe 1997-8 El Niño event.

Our analyses, consistent with previous reports for other taxa (Kelmo and Attrill, 2001; Attrill et al., 2004; Kelmo et al., 2003, 2004, 2006), revealed that the associated abiotic conditions that influenced the northern Bahia coral reef-associated organisms in 1998 were increased sea-surface temperature, increased solar radiation and reduced turbidity. We demonstrated that the 1997-8 event had a striking effect on the foraminiferal assemblages, including sharp declines in both symbiont-bearing taxa and the predominantly herbivorous and detritivorous species (Fig. 2).

Hallock (1987), Hallock et al. (1993a, b), Birkeland (1997), and others have recognized that nutrient availability on a local scale is a major control of benthic community structure, especially in subtropical and tropical seas. Very limited nutrient input tends to favour calcifying symbioses, for example zooxanthellate corals and foraminifers that host algal symbionts. Somewhat higher nutrient flux supports domination of the benthos by macroalgae and heterotrophic benthos, because symbiosis is less advantageous (Hallock, 1985; Birkeland, 1997). Even higher nutrient influx promotes phytoplankton blooms in the water column, limiting light penetration to the benthos and promoting the dominance of the non-symbiotic filter-feeding and the detritus-feeding animals.

Nutrient flux is strongly implicated as a major factor controlling the foraminiferal assemblages in the northern Bahian region. The notable abundance and diversity of smaller heterotrophic foraminifers, combined with the presence of a diverse but low density assemblage of symbiont-bearing species, indicates that overall environmental conditions are more optimal for the smaller heterotrophs than for symbiotic calcifiers, but still suitable for the latter. The decline of the smaller foraminifers during El Niño conditions was likely the consequence of reduced food supplies 
associated with reduced rainfall and runoff, as reflected in turbidity. Elevated temperatures also indirectly reduce food supplies by elevating metabolic rates.

However, from previous work on foraminifers and nutrients (e.g. Hallock et al., 2003; Uthicke et al., 2010), one would anticipate that foraminiferal taxa that host algal symbionts should increase in abundance when environmental perturbations reduce turbidity and food supplies. Earlier research on the energetic benefits of algal symbiosis (e.g. Hallock, 1981, 1985) suggests that this mode of life should be highly advantageous when dissolved nutrients and particulate food resources are scarce. Similarly, physiological studies of zooxanthellate corals (Falkowski et al., 1993; Steven and Broadbent, 1997) have shown that fixed-nitrogen limitation is crucial to maintenance of the host-symbiont relationship in zooxanthellate corals.

The striking decline in the densities of foraminifers that host algal symbionts in 1997-8 (Fig. 2) is, however, consistent with the more than $95 \%$ decline observed in A. gibbosa populations on the Florida Reef tract following an unprecedented bleaching episode in summer of 1991. That event so damaged reproductive potential that populations required several years to recover to pre-bleaching densities (e.g. Hallock et al., 1995; Williams et al., 1997). The decline in symbiont-bearing foraminifers on the northern Bahia reefs in 1997-8 was likely induced by photo-oxidative stress resulting from the combined effects of increased temperature and solar radiation. High irradiance alone can cause bleaching and mortality in Amphistegina spp. (Hallock et al., 1995, 2006). Additionally, exposure to elevated temperatures negatively impacts foraminifers health and impairs growth (Reymond et al., 2011; Uthicke et al., 2012), and when combined with excess visible or UV radiation, causes bleaching (Talge and Hallock, 2003).

Populations of small, heterotrophic foraminifers rebounded quickly from the 1997-8 El Niño event. However, after 2000, their densities declined and remained relatively low, with further declines during weaker El Niño conditions in 2007 and 2011, with significant losses of density and species richness in 2007, but not in 2011. In the context of the 17-year time series, the foraminiferal densities in 1995, 1996, 1999 and 2000 were unusually high, possibly related to rainfall peaks during relatively strong La Niña conditions. Moreover, since smaller foraminifers can quickly bloom in response to increased food supply, following El Niño-related mortality in corals, ascidians and other macrobenthos in 1998 (Kelmo and Attrill, 2001; Attrill et al., 2004; Kelmo et al., 2003, 2004, 2006), there simply may have been less competition for food in 1999 and 2000, allowing the rapid increase in those taxa. This bloom is reflected in the corresponding low in the FI during those years (Fig. 3), indicating that the larger, symbiont-bearing foraminiferal populations took somewhat longer to recover.

A note regarding the FI is needed here. This index was developed for assessing the "total" assemblage of foraminifers in the sediments, i.e. where all fresh-appearing specimens are identified and counted, without attempting to determine what was alive at the time of sampling. Sediments are not optimal habitat for foraminifers in reef environments. During calm weather, sediments can be stabilized for days to weeks during which time microalgae and microbes can produce mats into which some smaller taxa can recruit, grow and reproduce. Symbiont-bearing foraminifers tend to be larger in size and generally have life spans of several months to a year or more. Therefore their live occurrence in sediment samples reflects either accidental transport or recent development of propagules in microbial-mat stabilized sediment. Thus, the live (stained) foraminiferal assemblage in sediments, even in optimal reef environments, tend to be dominated by smaller, short-lived taxa. Moreover, the live assemblage seldom accounts for more than about $10-15 \%$ of the total assemblage (Martinez-Colón et al., 2009; and references therein). The death assemblage in sediments, on the other hand, integrates environmental conditions because that is where the dead shells accumulate, predominantly coming from nearby hard and phytal substrata, which is much more dependable habitat for most of these protists. However, the death assemblage is taphonomically altered because smaller, more fragile shells tend to be broken up or transported away. "Total" assemblage data thus reflect two counteracting biases: the live assemblage is dominated by small, fast-growing forms; the dead assemblage is dominated by taxa from the immediate vicinity, with selective loss of the smallest and most fragile shells. The basic assumption of the FI as proposed by Hallock et al. (2003) is that, if environmental conditions support dominance by calcifying symbioses (i.e. zooxanthellate corals and foraminifers with algal symbionts), at least $25 \%$ of the "freshappearing" shells should be from symbiont-bearing foraminifers; such counts will yield $\mathrm{FI} \geq 4$.

A few studies, including this one, have calculated FIs based on live assemblages, with the predictable results that the values tend to be lower than FIs based on total assemblages. The most comprehensive assessment was carried out by Carilli and Walsh (2012) in Kiritimati Islands in the Pacific, in which the live FI averaged 4.6 and the dead FI averaged 9.1. Unfortunately, they did not report total assemblage or even relative abundances of live to dead shells, so we cannot reconstruct the average FI for the total assemblage, other than conclude it was somewhere between 4.6 and 9.1. Stephenson (2011) compared total assemblages in rubble and sediment samples collected from the same sites (i.e. rubble in sand patches) on a Florida reef. The rubble samples, in which approximately $85 \%$ of the specimens were live when collected, produced a mean FI of 3.6. The sediment samples, in which approximately $15 \%$ were alive when collected, produced an FI of 5.6. Stephenson also calculated a "concentration ratio" based on relative abundances of the most common species; shells of the symbiont-bearing taxa tended to be 2-3 times more common in sediments while shells of smaller taxa were 2-3 times more common in the rubble samples.

While additional comparisons are needed to refine interpretations of the FI when based upon live assemblages, clearly the threshold for concern of FI 4 for healthy reefs, which was developed based on total assemblages, is too high for data based on live assemblages. Whether the threshold for concern when analyses are based on live assemblages should be $\sim 2.8-3$ (i.e. $10-15 \%$ symbiontbearing), or slightly higher, requires further assessment. However, the drop in the FI to $\sim 2.5$ that we observed following the 1997-8 stress event indicates the sensitivity of this reef-assessment metric.

\section{Conclusion}

The stress imposed by the strong 1997-8 El Niño-induced environmental conditions dramatically influenced the density and species richness the foraminiferal assemblage on shallow reefs of northern Bahia, including disappearance of several species. The environmental changes previously reported as detrimental to corals on these reefs (Kelmo et al., 2003) were also detrimental to the benthic foraminifers. We suggest that the combination of elevated temperature, reduced turbidity and therefore increased solar radiation reaching the reefs during the 1997-98 El Niño caused declines in the symbiont-bearing taxa. At the same time, the reduction in food resources reaching the seafloor associated with reduced nutrient runoff from land, that reduced phytoplankton in the water column as indicated by reduced turbidity, resulted in decline of the heterotrophic taxa dependent upon grazing and deposit feeding. In contrast, during strong La Nina-related conditions (1995-6 and 1999-2000) of increased rainfall and therefore increased runoff of terrestrial nutrients, densities and diversities of smaller foraminferal taxa peaked. Considering that ENSO-related environmental fluctuations are becoming stronger and more 
frequent (Timmerman et al., 1999), the consequences for the benthic reef foraminifers, as well as reef macrofauna, are inevitable. Thus, multi-year assessments of reef taxa, in addition to corals, are essential to expanding our knowledge of the longer-term consequences of this global event in the face of global environmental changes.

\section{Acknowledgements}

Thanks to FK students Luana Oliveira and Caio Damasceno for their help and assistance. Gratitude is expanded to Simone Moraes and Rilza Gomes for encouragement of this research for a number of years.

\section{Appendix A.}

\section{See Table A1}

\section{Table A1}

Similarity percentages analysis (SIMPER): species of foraminifera contributing most to the dissimilarity between ENSO years and non-ENSO years.

\begin{tabular}{|c|c|c|c|}
\hline \multirow[t]{2}{*}{ Species } & \multicolumn{2}{|c|}{ Average density } & \multirow{2}{*}{$\begin{array}{l}\text { Average } \\
\text { dissimilarity }\end{array}$} \\
\hline & $\begin{array}{l}\text { Non-ENSO } \\
\text { years }\end{array}$ & $\begin{array}{l}\text { ENSO } \\
\text { years }\end{array}$ & \\
\hline Amphistegina gibbosa & 2.67 & 0.62 & 0.39 \\
\hline Quinqueloculina bicostata & 3.97 & 2.61 & 0.35 \\
\hline Planispirella exigua & 4.01 & 2.72 & 0.35 \\
\hline Articulina atlântica & 2.32 & 0.56 & 0.34 \\
\hline Triloculina consobrina & 3.29 & 2.53 & 0.33 \\
\hline Pyrgo ringens & 2.49 & 0.92 & 0.33 \\
\hline Sigmoilina asperula & 3.29 & 2.08 & 0.32 \\
\hline Siphonina pulchra & 2.10 & 0.36 & 0.32 \\
\hline Miliolinella subrotunda & 3.89 & 3.04 & 0.32 \\
\hline Quinqueloculina quinquecarinata & 3.43 & 2.40 & 0.32 \\
\hline Spiroculina sp1 & 1.96 & 1.54 & 0.31 \\
\hline Miliolinella suborbicularis & 2.07 & 1.04 & 0.31 \\
\hline Triloculina oblonga & 3.40 & 2.23 & 0.31 \\
\hline Ammonia sp2 & 2.17 & 2.11 & 0.30 \\
\hline Peneroplis discoideus & 1.45 & 1.11 & 0.30 \\
\hline Discorbis sp1 & 2.56 & 1.80 & 0.30 \\
\hline Textularia gramen & 3.65 & 2.99 & 0.30 \\
\hline Liebusella soldani & 3.35 & 2.88 & 0.30 \\
\hline Cibicides aknerianus & 2.15 & 1.06 & 0.29 \\
\hline Sagrina pulchella & 3.36 & 2.52 & 0.29 \\
\hline Cymbaloporetta squammosa & 2.44 & 2.59 & 0.29 \\
\hline Quinqueloculina bosciana & 3.22 & 2.87 & 0.28 \\
\hline Quinqueloculina parkeri & 2.43 & 1.18 & 0.28 \\
\hline Cibicides dispars & 2.09 & 0.69 & 0.28 \\
\hline Cibicides pseudoungerianus & 2.69 & 2.72 & 0.27 \\
\hline Triloculina sp6 & 1.93 & 0.66 & 0.27 \\
\hline Spiroculina sp2 & 2.42 & 2.23 & 0.27 \\
\hline Triloculina elongata & 1.91 & 0.51 & 0.27 \\
\hline Triloculina gualtieriana & 2.06 & 0.78 & 0.26 \\
\hline Hauerina ornatissima & 2.17 & 1.08 & 0.26 \\
\hline Planorbulina mediterranensis & 1.87 & 0.66 & 0.26 \\
\hline Sphaeroidina bulloudes & 2.13 & 1.76 & 0.25 \\
\hline Borelis pulchra & 2.17 & 1.26 & 0.25 \\
\hline Baggina philippinensis & 2.72 & 2.24 & 0.25 \\
\hline Textularia candeiana & 3.15 & 2.60 & 0.25 \\
\hline Quinqueloculina polygona & 1.87 & 0.76 & 0.25 \\
\hline Articulina mucronata & 1.81 & 0.64 & 0.24 \\
\hline Massilina pernabucensis & 1.43 & 1.46 & 0.24 \\
\hline Quinqueloculina carinata & 1.93 & 0.88 & 0.24 \\
\hline Ammobaculites $s p 2^{\mathrm{b}}$ & 1.53 & 0.31 & 0.24 \\
\hline Bolivina compacta & 1.77 & 0.46 & 0.24 \\
\hline Peneroplis proteus & 1.54 & 1.57 & 0.24 \\
\hline Quinqueloculina auberiana & 2.07 & 0.90 & 0.24 \\
\hline Triloculina sp4 & 1.76 & 0.57 & 0.23 \\
\hline Dentostomina enoplostoma & 2.09 & 0.99 & 0.23 \\
\hline Siphoninoides echinatus & 1.62 & 0.68 & 0.23 \\
\hline Quinqueloculina derbyi & 1.74 & 0.96 & 0.23 \\
\hline Peneroplis $s p$ & 1.38 & 1.76 & 0.23 \\
\hline
\end{tabular}

Table A1 (Continued)

\begin{tabular}{|c|c|c|c|}
\hline \multirow[t]{2}{*}{ Species } & \multicolumn{2}{|c|}{ Average density } & \multirow{2}{*}{$\begin{array}{l}\text { Average } \\
\text { dissimilarity }\end{array}$} \\
\hline & $\begin{array}{l}\text { Non-ENSO } \\
\text { years }\end{array}$ & $\begin{array}{l}\text { ENSO } \\
\text { years }\end{array}$ & \\
\hline Triloculina sp5 & 1.75 & 0.57 & 0.23 \\
\hline Quinqueloculina seminulum & 1.72 & 0.95 & 0.23 \\
\hline Ammonia sp1 & 1.78 & 0.77 & 0.23 \\
\hline Articulina paucicostata & 1.80 & 1.01 & 0.23 \\
\hline Cornuspira involvens & 1.82 & 1.11 & 0.23 \\
\hline Discorbis peruvianus & 1.73 & 0.45 & 0.23 \\
\hline Spiroculina mosesi & 1.78 & 0.77 & 0.23 \\
\hline Glabratella mirabilis & 1.69 & 0.55 & 0.22 \\
\hline Triloculina gracilis & 1.89 & 0.76 & 0.22 \\
\hline Elphidium galvestonense & 1.81 & 0.71 & 0.22 \\
\hline Sagrinopsis advena & 1.87 & 0.84 & 0.22 \\
\hline Quinqueloculina kerimbatica & 1.66 & 0.73 & 0.22 \\
\hline Elphidium selsevense & 1.76 & 0.61 & 0.22 \\
\hline Quinqueloculina goesi & 1.92 & 0.69 & 0.22 \\
\hline Glabratella pileolus & 1.56 & 0.72 & 0.22 \\
\hline Siphogerina roxoi & 1.74 & 0.73 & 0.22 \\
\hline Cibicides candei & 1.54 & 0.39 & 0.22 \\
\hline Sigmoilina subpoyeana & 1.92 & 1.03 & 0.22 \\
\hline Spiroculina poeyana & 1.81 & 0.72 & 0.22 \\
\hline Pyrgo sp3 & 1.93 & 1.11 & 0.22 \\
\hline Quinqueloculina sulcata & 1.87 & 0.87 & 0.21 \\
\hline Dyocibicides perforata & 1.66 & 0.78 & 0.21 \\
\hline Pyrgo bulloides ${ }^{\mathrm{a}}$ & 1.22 & 0.56 & 0.21 \\
\hline Ammonia beccarii form trepida & 1.54 & 0.64 & 0.21 \\
\hline Quinqueloculina microcostata & 1.90 & 1.06 & 0.21 \\
\hline Nodobaculariella cassis & 1.54 & 1.17 & 0.21 \\
\hline Orbulina universa & 1.54 & 0.40 & 0.21 \\
\hline Amphistegina lessoni & 1.54 & 0.71 & 0.21 \\
\hline Discorbis sp3 & 1.92 & 0.85 & 0.21 \\
\hline Gypsina vesicularis & 1.53 & 0.56 & 0.21 \\
\hline Quinqueloculina pricei & 1.59 & 0.78 & 0.21 \\
\hline Triloculina baldai & 1.66 & 0.63 & 0.21 \\
\hline Rosalina floridana & 1.23 & 0.80 & 0.21 \\
\hline Discorbis sp2 & 1.74 & 0.61 & 0.21 \\
\hline Spiroculina communis & 1.84 & 1.08 & 0.21 \\
\hline Quinqueloculina bicornis & 1.67 & 0.80 & 0.21 \\
\hline Articulina antillarum & 1.78 & 0.88 & 0.21 \\
\hline Vaginulina sp1 & 1.56 & 0.56 & 0.21 \\
\hline Melonis affine & 1.63 & 0.63 & 0.21 \\
\hline Quinqueloculina magoi & 1.51 & 0.58 & 0.21 \\
\hline Quinqueloculina exsculpta & 1.37 & 1.13 & 0.20 \\
\hline Bulininella paralela & 1.42 & 0.71 & 0.20 \\
\hline Quinqueloculina patagonica & 1.12 & 1.04 & 0.20 \\
\hline Pyrgo sp1 & 1.33 & 0.81 & 0.20 \\
\hline Clavulina tricarinata $^{\mathrm{c}}$ & 1.02 & 0.63 & 0.20 \\
\hline Quinqueloculina angulata & 1.19 & 0.80 & 0.20 \\
\hline Quinqueloculina philippinensis & 1.52 & 0.76 & 0.20 \\
\hline Quinqueloculina planciana & 1.27 & 0.42 & 0.20 \\
\hline Articulina pacifica & 1.52 & 0.72 & 0.20 \\
\hline Fissurina semimarginata & 1.41 & 0.95 & 0.20 \\
\hline Lagena semistriata & 1.55 & 0.87 & 0.20 \\
\hline Quinqueloculina candeiana & 1.86 & 0.95 & 0.20 \\
\hline Cycloforina contorta & 1.09 & 1.26 & 0.20 \\
\hline Uvigerina auberiana & 1.60 & 0.75 & 0.20 \\
\hline Quinqueloculina disparilis curta & 1.68 & 1.47 & 0.20 \\
\hline Triloculina $s p 2^{\mathrm{a}, \mathrm{b}}$ & 1.27 & 0.06 & 0.20 \\
\hline Articulina sagra & 1.29 & 0.81 & 0.20 \\
\hline Spirillina vivipara & 1.32 & 0.83 & 0.20 \\
\hline Allomorphina lamegoi & 1.50 & 0.74 & 0.20 \\
\hline Quinqueloculina collumnosa & 1.29 & 1.16 & 0.20 \\
\hline Triloculina caudata & 1.34 & 0.69 & 0.20 \\
\hline Tubinella funalis & 1.40 & 0.60 & 0.20 \\
\hline Heterostegina sp1 & 1.33 & 0.49 & 0.20 \\
\hline Fischerina helix & 1.51 & 0.80 & 0.20 \\
\hline Glandulina rotundata & 1.39 & 0.55 & 0.19 \\
\hline Quinqueloculina atlantica & 1.66 & 0.85 & 0.19 \\
\hline Bigerina nodosaria & 2.13 & 1.26 & 0.19 \\
\hline Patellina corrugata & 1.82 & 1.21 & 0.19 \\
\hline Sigmolinita tenuis & 1.57 & 1.00 & 0.19 \\
\hline Quinqueloculina bicarinata & 1.48 & 0.92 & 0.19 \\
\hline Reophax fusiformis & 1.86 & 1.23 & 0.19 \\
\hline Quinqueloculina compta & 1.72 & 1.10 & 0.19 \\
\hline Quinqueloculina implexa & 1.65 & 1.00 & 0.19 \\
\hline
\end{tabular}


Table A1 (Continued)

\begin{tabular}{|c|c|c|c|c|c|c|c|}
\hline \multirow[t]{2}{*}{ Species } & \multicolumn{2}{|c|}{ Average density } & \multirow{2}{*}{$\begin{array}{l}\text { Average } \\
\text { dissimilarity }\end{array}$} & \multirow[t]{2}{*}{ Species } & \multicolumn{2}{|c|}{ Average density } & \multirow{2}{*}{$\begin{array}{l}\text { Average } \\
\text { dissimilarity }\end{array}$} \\
\hline & $\begin{array}{l}\text { Non-ENSO } \\
\text { years }\end{array}$ & $\begin{array}{l}\text { ENSO } \\
\text { years }\end{array}$ & & & $\begin{array}{l}\text { Non-ENSO } \\
\text { years }\end{array}$ & $\begin{array}{l}\text { ENSO } \\
\text { years }\end{array}$ & \\
\hline Archaias angulatus & 1.38 & 1.09 & 0.19 & Spiroculina caduca & 1.67 & 1.05 & 0.16 \\
\hline Wiesnerella auriculata & 1.37 & 0.59 & 0.19 & Dyocibicides biserialis & 1.32 & 0.88 & 0.16 \\
\hline Laevidentalina aphelis & 1.34 & 0.21 & 0.19 & Globulina caribaea & 1.39 & 0.94 & 0.16 \\
\hline Planorbulina acervalis & 1.49 & 0.56 & 0.19 & Gypsina globulus & 1.31 & 0.71 & 0.16 \\
\hline Quinqueloculina agglutinans & 1.21 & 1.16 & 0.19 & Elphidium sp3 & 1.25 & 0.51 & 0.16 \\
\hline Cancris sagra & 1.48 & 0.47 & 0.19 & Bolivina dottiana & 1.25 & 0.70 & 0.16 \\
\hline Quinqueloculina intricata & 1.70 & 1.01 & 0.19 & Tretomphalus atlanticus & 1.08 & 0.57 & 0.16 \\
\hline Bolivina limonensis & 1.70 & 0.79 & 0.19 & Pyrgo subsphaerica & 1.20 & 0.90 & 0.16 \\
\hline Tretomphalus bulloides & 1.42 & 0.55 & 0.19 & Triloculina sp3 & 1.11 & 0.36 & 0.16 \\
\hline Quinqueloculina lamarckiana & 1.35 & 1.14 & 0.19 & Vaginulina sp2 & 1.26 & 0.70 & 0.16 \\
\hline Reusella spinulosa & 1.36 & 0.23 & 0.19 & Fissurina perforata & 1.21 & 0.73 & 0.16 \\
\hline Pyrgo quadrata & 1.19 & 1.00 & 0.19 & Peneroplis carinatus & 0.97 & 0.67 & 0.16 \\
\hline Heterostegina sp3 & 1.30 & 0.38 & 0.19 & Heterostegina sp2 & 1.44 & 0.78 & 0.16 \\
\hline Cornuspira planorbis & 1.34 & 1.06 & 0.19 & Angulogerina angulosa occidentalis & 1.06 & 0.18 & 0.15 \\
\hline Quinqueloculina poeyana & 1.38 & 0.85 & 0.19 & Oolina hexagona & 1.24 & 0.78 & 0.15 \\
\hline Bulininella milleti & 1.39 & 0.73 & 0.18 & Quinqueloculina venusta ${ }^{\mathrm{a}, \mathrm{b}}$ & 1.13 & 0.09 & 0.15 \\
\hline Quinqueloculina arenata & 1.48 & 1.02 & 0.18 & Astacolus crepidatus ${ }^{\mathrm{b}}$ & 1.01 & 0.09 & 0.15 \\
\hline Pyrgo tainanensis & 1.28 & 0.90 & 0.18 & Hanzawaia concêntrica & 1.16 & 0.72 & 0.15 \\
\hline Eponides antillarum & 1.66 & 0.69 & 0.18 & Pyrgo nasuta ${ }^{\mathrm{b}}$ & 1.05 & 0.23 & 0.15 \\
\hline Quinqueloculina horrida & 1.49 & 0.59 & 0.18 & Pyrgo patagonica & 1.19 & 0.09 & 0.15 \\
\hline Vaginulina sp3 & 1.32 & 0.60 & 0.18 & Elphidium poeyanum & 1.35 & 0.90 & 0.15 \\
\hline Sigmavirgulina tortuosa & 1.24 & 0.67 & 0.18 & Reophax atlantica & 1.68 & 1.17 & 0.15 \\
\hline Lenticulina limbosa & 1.26 & 0.50 & 0.18 & Reusella sp1 & 1.08 & 0.55 & 0.15 \\
\hline Bolivina doniezi & 1.55 & 0.75 & 0.18 & Triloculina laevigata & 1.39 & 1.03 & 0.15 \\
\hline Quinqueloculina cuvieriana & 1.42 & 1.32 & 0.18 & Rectobolivina euzebioi & 1.25 & 0.75 & 0.15 \\
\hline Hauerina fragilissima & 1.78 & 1.63 & 0.18 & Glandulina vítrea & 1.03 & 0.63 & 0.15 \\
\hline Articulina multilocularis & 1.66 & 0.94 & 0.18 & Carterina spiculotesta ${ }^{\mathrm{a}, \mathrm{b}}$ & 0.98 & 0.23 & 0.15 \\
\hline Pyrgo sp2 & 1.22 & 0.84 & 0.18 & Bombulina spinata & 1.23 & 0.80 & 0.14 \\
\hline Articulina mexicana & 1.54 & 0.88 & 0.18 & Cibicides sp2 & 0.98 & 0.71 & 0.14 \\
\hline Homotrema rubra & 1.43 & 0.84 & 0.18 & Discorbis bertheloti ${ }^{\mathrm{a}}$ & 1.02 & 0.09 & 0.14 \\
\hline Pseudononion grateloupi & 1.59 & 0.66 & 0.18 & Elphidium sp1 & 0.98 & 0.43 & 0.14 \\
\hline Fursenkoina punctata & 1.07 & 0.69 & 0.18 & Elphidium discoides & 1.07 & 0.76 & 0.14 \\
\hline Poroeponides sp $2^{\mathrm{b}}$ & 1.17 & 0.32 & 0.18 & Bolivina sp2 & 0.90 & 0.86 & 0.14 \\
\hline Textularia conica & 1.68 & 1.02 & 0.18 & Vaginulina sp4 & 0.95 & 0.18 & 0.14 \\
\hline Angulogerina angulosa angulosa & 1.24 & 0.30 & 0.18 & Guttulina problema & 0.82 & 0.24 & 0.14 \\
\hline Lagena laevis & 1.38 & 0.84 & 0.18 & Articulina sp5 & 0.60 & 0.57 & 0.13 \\
\hline Heterostegina depressa & 1.32 & 0.55 & 0.18 & Triloculina quadrilateralis ${ }^{\mathrm{b}}$ & 0.93 & 0.16 & 0.13 \\
\hline Ammonia beccarii form parkinsoniana & 1.27 & 0.87 & 0.18 & Triloculina $\mathrm{sp} 1^{\mathrm{b}}$ & 0.85 & 0.13 & 0.13 \\
\hline Loxostomum limbatum & 1.33 & 0.60 & 0.18 & Heterostegina sp4 & 0.76 & 0.38 & 0.13 \\
\hline Textularia kerimbaensis & 1.58 & 1.10 & 0.18 & Triloculina planciana ${ }^{\mathrm{a}}$ & 1.00 & 0.09 & 0.13 \\
\hline Edentostomina cultrata & 1.15 & 0.69 & 0.18 & Articulina sp1 & 0.40 & 0.67 & 0.13 \\
\hline Sigmoillopsis minuta & 1.50 & 0.82 & 0.18 & Textularia agglutinans & 1.32 & 1.02 & 0.13 \\
\hline Archaias $s p$ & 1.69 & 0.86 & 0.17 & Articulina sp2 & 0.46 & 0.57 & 0.12 \\
\hline Sigmoidella elegantíssima & 1.21 & 0.77 & 0.17 & Pyrgo denticulata ${ }^{\mathrm{C}}$ & 0.79 & 0.00 & 0.12 \\
\hline Elphidium sp2 & 1.39 & 0.63 & 0.17 & Articulina sp4 & 0.31 & 0.61 & 0.12 \\
\hline Bulininella seminuda & 1.24 & 0.65 & 0.17 & Articulina sp3 & 0.32 & 0.62 & 0.12 \\
\hline Lepidodeuteramina ochracea ${ }^{\mathrm{a}}$ & 0.80 & 0.53 & 0.17 & Pyrgo sp $4^{\mathrm{a}, \mathrm{b}}$ & 0.82 & 0.00 & 0.12 \\
\hline Spirillina limbata & 1.25 & 1.18 & 0.17 & Triloculina tricarinata ${ }^{\mathrm{a}}$ & 0.88 & 0.09 & 0.12 \\
\hline Poroeponides lateralis & 1.56 & 0.72 & 0.17 & Triloculina trigonula & 0.89 & 0.09 & 0.12 \\
\hline Rosalina globularis & 1.25 & 0.54 & 0.17 & Triloculina linneiana & 0.87 & 0.09 & 0.12 \\
\hline Peneroplis pertusus & 0.88 & 0.53 & 0.17 & Spirosigmoilina bradyi & 0.86 & 0.09 & 0.12 \\
\hline Lagena sulcata & 1.41 & 0.61 & 0.17 & Ammobaculites sp $1^{\mathrm{b}}$ & 0.67 & 0.18 & 0.11 \\
\hline Sorites marginalis & 1.37 & 0.84 & 0.17 & Triloculina quadrata & 0.75 & 0.13 & 0.11 \\
\hline Bolivina subexcavata & 1.67 & 1.12 & 0.17 & Triloculina sommeri ${ }^{\mathrm{a}}$ & 0.80 & 0.09 & 0.11 \\
\hline Elphidium sagrum & 1.20 & 0.55 & 0.17 & Triloculina reticulata form carinata & 0.84 & 0.09 & 0.11 \\
\hline Poroeponides sp1 & 1.22 & 0.51 & 0.17 & Poroeponides sp $3^{\mathrm{a}}$ & 0.70 & 0.18 & 0.11 \\
\hline Cibicides sp 1 & 1.35 & 0.66 & 0.17 & Rosalina $s p^{a}$ & 0.70 & 0.18 & 0.11 \\
\hline Elphidium incertum & 1.43 & 0.73 & 0.17 & Triloculina reticulata form bicarinata ${ }^{\mathrm{a}}$ & 0.67 & 0.09 & 0.09 \\
\hline Neoconorbina orbicularis & 1.25 & 0.87 & 0.17 & Peneroplis bradyi & 0.65 & 0.00 & 0.07 \\
\hline Bolivina sp1 & 1.08 & 0.76 & 0.17 & Textularia $s p 1^{\mathrm{c}}$ & 0.49 & 0.09 & 0.07 \\
\hline Discorbis mira & 1.24 & 0.63 & 0.17 & Textularia $s p 3^{c}$ & 0.54 & 0.00 & 0.06 \\
\hline Brizalina striatula & 1.37 & 1.06 & 0.17 & Textularia sp $4^{\mathrm{c}}$ & 0.52 & 0.00 & 0.06 \\
\hline Quinqueloculina moynensis & 1.12 & 0.60 & 0.17 & Schlumbergerina alveoliniformis ${ }^{c}$ & 0.40 & 0.00 & 0.06 \\
\hline Rosalina candeiana & 1.30 & 0.55 & 0.17 & Textularia $s p 2^{c}$ & 0.50 & 0.00 & 0.05 \\
\hline Siphogerina raphanus & 1.57 & 0.98 & 0.17 & Textularia sp5 $5^{c}$ & 0.48 & 0.00 & 0.05 \\
\hline Triloculina lutea & 1.87 & 1.42 & 0.17 & Pyrgo elongata ${ }^{\mathrm{b}}$ & 0.46 & 0.00 & 0.05 \\
\hline Pseudononion atlanticum & 1.37 & 0.54 & 0.16 & Textularia $s p 6^{\mathrm{b}}$ & 0.45 & 0.00 & 0.05 \\
\hline Elphidium fimbriatulum & 1.43 & 0.62 & 0.16 & Quinqueloculina $s^{c} 6^{c}$ & 0.33 & 0.00 & 0.03 \\
\hline Acervulina inhaerens & 1.33 & 0.96 & 0.16 & Quinqueloculina $s p 1^{\mathrm{c}}$ & 0.22 & 0.00 & 0.03 \\
\hline Fursenkoina pontoni & 1.23 & 0.66 & 0.16 & Quinqueloculina sp8c & 0.18 & 0.00 & 0.02 \\
\hline Eponides repandus & 1.48 & 0.73 & 0.16 & Quinqueloculina $s p 7^{c}$ & 0.18 & 0.00 & 0.02 \\
\hline Spiroculina stebani & 1.01 & 0.69 & 0.16 & Pyrgo sp $5^{\mathrm{c}}$ & 0.18 & 0.00 & 0.02 \\
\hline Quinqueloculina vulgaris ${ }^{\mathrm{b}}$ & 1.19 & 0.18 & 0.16 & Clavulina sp1 & 0.10 & 0.00 & 0.02 \\
\hline
\end{tabular}


Table A1 (Continued)

\begin{tabular}{llll}
\hline Species & Average density & & $\begin{array}{l}\text { Average } \\
\text { dissimilarity }\end{array}$ \\
\cline { 2 - 3 } & $\begin{array}{l}\text { Non-ENSO } \\
\text { years }\end{array}$ & $\begin{array}{l}\text { ENSO } \\
\text { years }\end{array}$ & \\
\hline Pyrgo sp7c & 0.14 & 0.00 & 0.02 \\
Quinqueloculina sp2 $^{c}$ & 0.15 & 0.00 & 0.02 \\
Quinqueloculina sp5 $^{c}$ & 0.14 & 0.00 & 0.01 \\
Pyrgo sp6 $^{c}$ & 0.12 & 0.00 & 0.01 \\
Quinqueloculina sp4c $^{c}$ & 0.12 & 0.00 & 0.01 \\
Quinqueloculina sp3c $^{c}$ & 0.09 & 0.00 & 0.01 \\
\hline
\end{tabular}

a Unrecorded after 1997-8 ENSO.

b Unrecorded after 2006-7 ENSO.

c Recorded only during 1999-2000.

\section{References}

Almasi, M.N., 1978. Ecology and color variation of benthic foraminifera in Barnes Sound, Northeast Florida Bay. Masters Thesis, Rosentiel School of Marine and Atmospheric Science, University of Miami, Miami. 144 p.

Andrade, E.J., 1997. Distribuição dos foraminíferos recentes na transição carbonato/siliciclastos na região da Praia do Forte, Litoral Norte do Estado da Bahia. Dissertação de Mestrado, Instituto de Geociências, Universidade Federal da Bahia, Salvador. $111 \mathrm{p}$.

Attrill, M.J., Kelmo, F., 2007. Opportunistic responses of Diadema antillarum (Echinodermata:Echinoidea) populations following the 1997-98 El Niño event in Bahia, Brazil. Estuar. Coast. Shelf Sci. 73, 243-248.

Attrill, M.J., Kelmo, F., Jones, M.B., 2004. Impact of the 1997-8 El Niño event on the coral reef-associated echinoderm assemblage from Northern Bahia, NE Brazil. Climate Res. 26, 151-158.

Barbosa, C.F., Prazeres, M.F., Ferreira, B.P., Seoane, J.C.S., 2009. Foraminiferal assemblage and reef check census in coral reef health monitoring of East Brazilian margin. Mar. Micropaleontol. 73, 62-69.

Barker, R.W., 1960. Taxonomic Notes. Society of Economic Paleontologists and Mineralogists, Oklahoma, $238 \mathrm{p}$

Birkeland, C., 1997. Geographic differences in ecological processes on coral reefs. In: Bikerland, C. (Ed.), Life and Death of Coral Reefs. Chapman Hall, New York, pp. $12,273-287$.

Bittencourt, A.C.S.P., Dominguez, J.M.L., Martin, L., Silva, I.R., 2000. Patterns of sediment dispersion coastwise the State of Bahia-Brazil. An. Acad. Bras. Cienc. 72, 271-287.

Bock, W.D., Hay, W.W., Jones, J.I., Lynts, G.W., Smith, S.L., Wright, R.C., 1971. In: Jones, J.I., Bock, W.D. (Eds.), A symposium of recent south Florida foraminifera. Miami Geological Society, Memoir 1.

Boltovskoy, E., Giussani, G., Watanabe, S., Wright, R., 1980. Atlas of Benthic Shelf Foraminifera of the Southwest Atlantic. Dr. W. Junk bv Publishers, Boston, p. 147.

Bray, J.R., Curtis, J.T., 1957. An ordination of the upland forest communities of southern Wisconsin. Ecol. Monogr. 27, 325-349.

Carnahan, E.A., Hoare, M.M., Hallock, P., Lidz, B.H., Reich, C.D., 2009. Foraminiferal assemblages in Biscayne Bay, Florida, USA: responses to urban and agricultural influence in a subtropical estuary. Mar. Pollut. Bull. 59, 221-233.

Carilli, J., Walsh, S., 2012. Benthic foraminiferal assemblages from Kiritimati (Christmas) Island indicate human-mediated nitrification has occurred over the scale of decades. Mar. Ecol. Prog. Ser. 456, 87-99.

Carr, M.R., 1996. Plymouth Routines in Multivariate Analysis. Primer User Manual. Natural Environment Research Council, Swindon, UK, 45 p.

Clarke, K.R., 1993. Non-parametric multivariate analysis of changes in community structure. Aust. J. Ecol. 18, 117-143.

Clarke, K.R., Ainsworth, M., 1993. A method of linking multivariate community structure to environmental variables. Mar. Ecol. Prog. Ser. 92, 205-219.

Clarke, K.R., Green, R.H., 1988. Statistical design and analysis for a 'biological effects' study. Mar. Ecol. Prog. Ser. 46, 213-226.

Clarke, K.R., Warwick, R.M., 1994. Change in Marine Communities: An Approach to Statistical Analysis and Integration. Natural Environment Research Council, Swindon, UK, $144 \mathrm{p}$

Closs, D., Barberena, M.C., 1960. Foraminíferos recentes da praia do Cassino (Rio Grande RS). Boletim, Escola de Geologia de Porto Alegre 5, 1-29.

Corliss, B.H., Emerson, C., 1990. Distribution of Rose Bengal stained deep-sea benthic foraminifera from the Nova Scotian continental margin and Gulf of Maine. Deep Sea Res. 37, 381-400.

Falkowski, P.G., Dubinsky, Z., Muscatine, L., McCloskey, L., 1993. Population control in symbiotic corals. Bioscience 43, 606-611.

Glynn, P.W., Matt, J.L., Baker, A.C., Calderon, M.O., 2001. Coral bleaching and mortality in Panama and Ecuador during the 1997-1998 El Niño Southern Oscillation event: spatial/temporal patterns and comparison with the 1982-1983 event. Bull. Mar. Sci. 69, 79-109.

Hallock, P., 1981. Light dependence in Amphistegina. J. Foraminiferal Res. 11, 40-46.

Hallock, P., 1985. Why are larger Foraminifera large? Palaeobiology 11, 195-208.
Hallock, P., 1987. Fluctuations in the trophic resource continuum: a factor in global diversity cycles? Paleoceanography 2, 457-471.

Hallock, P., Lidz, B.H., Cockey-Burkhard, E.M., Donnelly, K.B., 2003. Foraminifera as bioindicators in coral reef assessment and monitoring: the FoRAM index. Environ. Monit. Assess. 81, 221-238.

Hallock, P., Muller-Karger, F.E., Halas, J.C., 1993a. Coral reef decline-anthropogenic nutrients and the degradation of western Atlantic and Caribbean coral reefs. Res. Explor. 9, 358-378.

Hallock, P., Talge, H.K., Smith, K., Cockey, E.M., 1993b. Bleaching in reef-dwelling foraminifera Amphistegina gibbosa. In: Proceedings of 7th Internat Coral Reef Symposium, vol. 1, Guam, pp. 44-49.

Hallock, P., Talge, H.K., Cockey, E.M., Muller, R.G., 1995. A new disease in reefdwelling foraminifera: implications for costal sedimentation. J. Foraminiferal Res. 25, 280-286.

Hallock, P., Williams, D.E., Toler, S.K., Fisher, E.M., Talge, H.K., 2006. Bleaching in reef-dwelling foraminifers: implication for reef decline. In: Proceedings of 10th Internat Coral Reef Symposium, Okinawa, Japan, June 2004, pp. 729-737.

Kelmo, F., 1998. Caracterização do branqueamento de corais no recife costeiro da praia de Guarajuba, litoral norte do Estado da Bahia. Dissertação de Mestrado Curso de Pós-Graduacão em Geologia, Instituto de Geociências da Universidade Federal da Bahia, Salvador. 104 p.

Kelmo, F., 2002. Ecological consequences of the 1997-98 El Niño Southern Oscillation on the major coral reef communities from northern Bahia, Brazil. Ph.D Thesis, University of Plymouth, Plymouth, UK

Kelmo, F., Attrill, M.J., 2001. Cnidarian community structure of coastal reefs from Northern Bahia, Brazil. Bull. Mar. Sci. 69, 547-557.

Kelmo, F., Attrill, M.J., Gomes, R.C.T., Jones, M.B., 2004. El Niño induced local extinction of coral reef bryozoan species from Northern Bahia, Brazil. Biol. Conserv. $118,609-617$

Kelmo, F., Attrill, M.J., Jones, M.B., 2003. Effects of the 199798 El Niño on the cnidarian community of a high turbidity coral reef system (Northern Bahia, Brazil). Cora Reefs 22, 541-550.

Kelmo, F., Attrill, M.J., Jones, M.B., 2006. Mass mortality of coral reef ascidians following the 1997/1998 El Niño event. Hydrobiologia 555, 231-240.

Koukousioura, O., Dimiza, M.D., Triantaphyllou, M.V., Hallock, P., 2011. Living benthic foraminifera as an environmental proxy in coastal ecosystems: a case study from the Aegean Sea (Greece, NE Mediterranean). J. Mar. Syst. 88, 489-501.

Kumar, A., Wang, W.Q., Hoerling, M.P., Leetmaa, A., 2001. The sustained North American warming of 1997 and 1998. J. Clim. 14, 345-353.

Langer, M.R., 2008. Assessing the contribution of foraminiferan protists to globa ocean carbonate production. J. Eukaryot. Microbiol. 55, 163-169.

Langer, M.R., Silk, M.T., Lipps, J.H., 1997. Global ocean carbonate and carbon dioxide production: the role of reef foraminifera. J. Foraminiferal Res. 27 271-277.

Leão, Z.M.A.N., Kikuchi, R.K.P., Maia, M.P., Lago, R.A.L., 1997. A catastrophic coral cover decline since 3000 years BP, Northern Bahia, Brazil. In: Proceedings of 8th Internat Coral Reef Symposium, vol. 1, Panama, 1996, pp. 583-588.

Leipnitz, I.I. 1991. Ocorrência das ammodiscaceas e lituolaceas em sedimentos recentes da plataforma continental e do talude norte do Brasil (desembocadura do Rio Amazonas ao Cabo Orange). Acta Geol. Leopoldensia 33, 129-152.

Leipnitz, I.I., Leipnitz, B., Beckel, J., 1992. Ocorrência de miliolaceas em sedimentos recentes da plataforma continental e do talude do norte do Brasil (desembocadura do Rio Amazonas ao Cabo Orange). Acta Geol. Leopoldensia 36, 5-30.

Levy, A., Mathieu, R., Poignant, A., Rosset-Moulinier, M., Ubaldo, M.L., Lebreiro, S. 1995. Foraminifères actuels de la marge continentale portugaise-inventaire et distribution, vol. 32. Mem. Inst. Geol. Min, Lisboa.

Machado, A.J., 1981. Foraminíferos dos sedimentos superficiais e subsuperficiais (Plio/Holoceno) da margem continental do Maranhão. Instituto de Geociências, Universidade Federal do Rio Grande do Sul, Porto Alegre, Tese de Doutoramento, $173 \mathrm{p}$.

Machado, A.J., Andrade, E.J., Araújo, H.A.B., 2006. Fauna de foraminíferos do litoral norte do estado da Bahia. Rev. Geol. 19, 147-154.

Martinez-Colón, M., Hallock, P., Green-Ruíz, C., 2009. Strategies for using shallowwater benthic foraminifers as bioindicators of potentially toxic elements: a review. J. Foraminiferal Res. 39, 278-299.

Moraes, S.S., 2001. Interpretações da hidrodinâmica e dos tipos de transporte a partir de análises sedimentologias e do estudo dos foraminíferos recentes dos recifes costeiros da Praia do Forte e de Itacimirim, litoral norte do Estado da Bahia. Dissertação de Mestrado, Instituto de Geociências, Universidade Federal da Bahia, Salvador. 64 p.

Moraes, S.S., 2006. Distribuição e tafonomia de foraminíferos na plataforma continental da região norte da costa do dendê (Foz do Rio Jequiriçá à Ponta dos Castelhanos) Bahia Ph. D Thesis, Universidade Federal da Bahia, Salvador, Brazil.

Murray, J.W., Bowser, S.S., 2000. Mortality, protoplasm decay rate, and reliability of staining techniques to recognize living foraminifera: a review. J. Foraminiferal Res. 30, 66-70.

Narayan, Y.R., Pandolfi, J.M., 2010. Benthic foraminiferal assemblages from Moreton Bay, South-East Queensland, Australia: applications in monitoring water and substrate quality in subtropical estuarine environments. Mar. Pollut. Bull. 60 2062-2078.

Narchi, W., 1956. Foraminíferos recentes do Brasil, famílias Miliolidae, Peneroplidae e Alveolineliidae. Sep. Inst. Oceanogr. 7 (1/2), 161-192.

Nolasco, M.C., Leão, Z.M.A.N., 1986. The carbonate buildups along the northern coast of the State of Bahia, Brazil. In: Rabassa, J. (Ed.), Quaternary of South America and Antarctic Peninsula. Balkema Publishers, The Netherlands, pp. 159-190. 
Reymond, C., Uthicke, S., Pandolfi, J., 2011. Inhibited growth of the photosymbiontbearing foraminifera Marginopora vertebralis from the near shore Great Barrier Reef. Mar. Ecol. Prog. Ser. 435, 97-109.

Rodrigues, R.R., Haarms, R., Campos, E.D.J., Ambrizzi, T., 2011. The impacts of inter-El Niño variability on the tropical Atlantic and northeast Brazil climate. J. Clim. 24, 3402-3422.

Rossi, A., 1999. Foraminíferos quaternários do Arquipélago de Fernando de Noronha: taxonomia, ecologia, distribuição batimétrica e faciológica. MSc Dissertation, Universidade do Vale do Rio dos Sinos. 141 p.

Schafer, C.T., 2000. Monitoring nearshore marine environments using benthic foraminifera: some protocols and pitfalls. Micropaleontology 46, 161-169.

Stephenson, C.M., 2011. Foraminiferal Assemblages on Sediments and Reef Rubble at Conch Reef, Florida USA. Master of Science Thesis, University of South Florida, Tampa, FL, USA. <http://scholarcommons.usf.edu/ cgi/viewcontent.cgi?article=4562\& context $=$ etd $>$ (accessed 28.11.12).

Steven, A.P.L., Broadbent, A.D., 1997. Growth and metabolic responses of Acropora palifera to long-term nutrient enrichment. In: Proceedings of 8th Internat Coral Reef Symposium, vol. 1, Panama, pp. 867-872.

Talge, H.K., Hallock, P., 2003. Ultrastructural responses in fieldbleached and experimentally stressed Amphistegina gibbosa (Class Foraminifera). J. Eukaryot. Microbiol. 50, 324-333.
Timmerman, A., Oberhuber, J., Bacher, A., Esch, M., Latif, M., Roeckner, E., 1999. Increased El Niño frequency in a climate model forced by future greenhouse warming. Nature 398, 694-697.

Tinoco, I.M., 1955. Foraminíferos recentes de Cabo Frio, Estado do Rio de Janeiro. DNPM/DGM., Rio de Janeiro.

Tinoco, I.M., 1958. Foraminíferos quaternários de Olinda, Estado de Pernambuco, Rio de Janeiro. Departamento Nacional de Produção Mineral do Ministério da Agricultura, $61 \mathrm{p}$.

Uthicke, S., Thompson, A., Schaffelke, B., 2010. Effectiveness of benthic foraminiferal and coral assemblages as water quality indicators on inshore reefs of the Great Barrier Reef, Australia. Coral Reefs 29, 209-225.

Uthicke, S., van Dam, J.W., Negri, A.P., Mueller, J.F., Altenburger, R., 2012. Additive pressures of elevated sea surface temperatures and herbicides on symbiontbearing foraminifera. PLoS ONE 7, e33900.

Walton, W.R., 1952. Techniques for recognition of living foraminifera. Contrib. Cushman Found. Foraminiferal Res. 3, 56-60.

Ward, J.N., Pond, D.W., Murray, J.W., 2003. Feeding of benthic foraminifera on diatoms and sewage-derived organic matter: an experimental application of lipid biomarker techniques. Mar. Environ. Res. 56, 515-530.

Williams, D.E., Hallock, P., Talge, H.K., Harney, J.N., McRae, G., 1997. Responses of Amphistegina gibbosa populations in the Florida Keys (USA) to a multi-year stress event (1991-1996). J. Foraminiferal Res. 27, 264-269. 